\title{
IMPLICATIONS FOR FINANCING RESULTS ON MUDHARABAH FINANCING VOLUME IN BANK MANDIRI SYARI'AH
}

\author{
Ani Lusiani \\ Institut Agama Islam Darussalam (IAID) Ciamis-Jawa Barat \\ Email: ani.lusiani@gmail.com \\ Sumarni \\ Institut Agama Islam Darussalam (IAID) Ciamis-Jawa Barat \\ Received: 12 Nov 2019 \\ Accepted: 2 Feb 2020
}

\begin{abstract}
This research is motivated by the decrease of mudharabah financing volume from 2016-2019, while the share of financing increased except in 2018 at Bank Syariah Mandiri. From the observation, there is a negative relationship, whereas some previous research mentions that there is a positive relationship between the volume of financing mudharabah with profit sharing. It is exciting to know more about the volume of financing mudharabah with profit-sharing at Bank Syariah Mandiri year 2016-2019. The method used is the correlational descriptive method. The data used are monthly financial reports of mudharabah financing and profit-sharing of Bank Syariah Mandiri in 2016-2019. Data collection techniques used are document studies with data collection instruments browsing. Data analysis used descriptive statistics with Spearman Rank correlation technique because distributed research data is not normal. The descriptive statistics of mudharabah financing volume data and the share of financing at Bank Syariah Mandiri from January 2016 to December 2019 have increased and decreased. Spearman Rank correlation calculation results for the relationship of mudharabah financing volume with the financing sharing at Bank Syariah Mandiri in 2016-2019 is equal to -0.259 with a significance level of 0.046 at the level of $5 \%$ confidence. The conclusion is the volume of mudharabah financing with profit-sharing in Bank Syariah Mandiri in 2016-2019 has a weak correlation with a negative direction of -0.259 or $-25.9 \%$.
\end{abstract}

Abstrak
Penelitian ini dilatarbelakangi oleh penurunan volume pembiayaan mudharabah dari
tahun 2013-2019, sedangkan porsi pembiayaan meningkat kecuali pada tahun 2018
pada Bank Syariah Mandiri. Dari hasil pengamatan terdapat hubungan yang negatif,
padahal beberapa penelitian sebelumnya menyebutkan bahwa terdapat hubungan
positif antara volume pembiayaan mudharabah dengan bagi hasil. Menarik untuk
mengetahui lebih dalam tentang volume pembiayaan mudharabah dengan bagi hasil di
Bank Syariah Mandiri tahun 2016-2019. Metode yang digunakan adalah metode
deskriptif korelasional. Data yang digunakan adalah laporan keuangan bulanan
pembiayaan mudharabah dan bagi hasil Bank Syariah Mandiri tahun 2016-2019.
Teknik pengumpulan data yang digunakan adalah studi dokumen dengan instrumen
pengumpulan data browsing. Analisis data menggunakan statistik deskriptif dengan
teknik korelasi Rank Spearman karena data penelitian yang didistribusikan tidak
normal. Statistik deskriptif data volume pembiayaan mudharabah dan porsi
pembiayaan di Bank Syariah Mandiri periode Januari 2016 sampai dengan Desember
2019 mengalami kenaikan dan penurunan. Hasil perhitungan korelasi Rank Spearman
untuk hubungan volume pembiayaan mudharabah dengan bagi hasil pada Bank
Syariah Mandiri tahun 2016-2019 adalah sebesar -0,259 dengan tingkat signifikansi

https://riset-iaid.net/index.php/SE 
0,046 pada tingkat kepercayaan $5 \%$. Kesimpulannya volume pembiayaan mudharabah dengan bagi hasil di Bank Syariah Mandiri tahun 2016-2019 memiliki korelasi yang lemah dengan arah negatif sebesar -0,259 atau -25,9\%.

Keywords: Bank Syari’ah, Mudharabah Financing, Profit-Sharing.

\section{Introduction}

Sharia bank is a bank that runs its business activities based on Shariah principles. Basically, the products offered by syariah banks can be divided into three major sections: capital raising products, capital distribution products, and service products (Karim, 2003: 85).

The product of capital disbursement in syariah bank is called financing. One of the principles of financing is profit sharing with the mudaraba contract. Mudharabah is one of the financing with profit sharing principle. Mudharabah is the cooperation between the owner of capital (shahibul mal) with the capital manager (mudharib). The capital owner fully gives his capital to the manager in implementing the business project with the profit divided according to the agreement. The shahibul mall bears the losses incurred. Through mudharabah both parties who partner will not get interest, but get a share of the economic projects that are mutually agreed (Muhammad, 2002: 103).

This study chose Bank Syariah Mandiri (BSM), because the Syariah bank which was established in 1999 is the largest Syariah bank with assets in Indonesia. The volume of mudharabah financing at Bank Syariah Mandiri has decreased from 20132019, for profit-sharing results increased every year, except in 2018. The result of observation while the researcher is that there is a negative relationship between the volume of financing mudharabah with profit-sharing in Bank Syariah Mandiri in 20162019.

Previous research by Giannini (2013: 102) examines the factors affecting mudharabah financing in sharia banks in Indonesia in 2010-2016 using 6 Sharia Commercial Banks. One of the mudharabah financing factors studied is the profitsharing rate. From the research results obtained, the profit sharing rate has a significant positive effect on mudharabah financing, shown by the magnitude of coefficient of 0.488 or $48.8 \%$. It means that the higher level of profit sharing in a syari'ah bank will increase the amount of mudharabah financing.

Based on the available data, the researcher's temporary observation is a negative relationship. In contrast, previous research states a positive relationship between the volume of mudharabah financing with the financing share. It makes researchers want to know more about the relationship of mudharabah financing volume with the financing sharing at Bank Syariah Mandiri in 2016-2019. 


\section{Theoretical Review}

\section{Syariah Bank Concept}

The word bank comes from the Latin banco, a bench or table (Soemitra, 2009: 62). In the 12th century, the word banco referred to a money changer. The bank is a company engaged in finance, meaning that banking activities are always related in the field of finance (Cashmere, 2018: 24). Actions, in this case, are to raise capital (funding) from the community and channeled back to the community (financing) to support the economic growth of a country. Sharia bank operates by not relying on interest (Muhammad, 2005: 1). In other words, syariah bank is a financial institution whose operation is adjusted to Islamic syariah principles. The birth of this shari'ah bank makes Muslims avoid the system of interest, usury transactions, and other transactions prohibited by Islamic shari'ah.

\section{Mudharabah}

Mudharabah is derived from fi'il madhi ضرب, which means hitting or walking (Jonah, 1973: 227). The notion of hitting or walking is more precisely the process of a person banging his legs by running a business (Antonio, 1999: 135). Mudharabah belongs to one form of syirkah contract. Susyanti (2019: 16), holds that mudharabah is an intermediary between the first party (shahibul mal) provides the fund and the second party (mudharib) is responsible for the management of the business, the profit is divided according to the ratio of profit which has been agreed together advance, when the loss of shahibul the mall will lose some of the hard work and managerial skills (managerial skills) during the project.

Implementation of financing of mudharabah contract in syari'ah bank is bank provides financing of investment capital or working capital in full (trusty financing). In contrast, client provides project or business complete with its management and result of profit or loss in investment divided or shared by bank and customer according to agreement (Janwari, 2019: 59).

\section{Profit Sharing}

In its operation, the Shariah bank uses the principle of profit sharing. According to the term, profit-sharing is a system that includes the procedure for the distribution of business results between the provider of funds and fund managers (Rafiq, 2004: 153). In the shariah financial mechanism, the share is related to fundraising (funding) or funding or financing. Fatwa DSN MUI No. 15/DSN-MUI/IX/2000 allows the use of two types of revenue sharing methods, namely revenue sharing and profit-sharing (FORDEBY and ADESy, 2019: 293). The difference between these methods is the amount that is the basis of division, where the revenue sharing method is based on gross profit while profit sharing is based on net income. Factors affecting the size of the profit-sharing are grouped into direct factors such as the investment rate, the number of funds invested, and the ratio. The second factor is indirect factors such as the determination of income points and mudharabah fees, and accounting policies. 


\section{Method}

This type of research is quantitative with a correlational descriptive research method. The correlational descriptive method is a research method by describing the object under study to know the relationship between variables therein. The relationship can be a direct or opposite direction. The object of this research is Bank Syariah Mandiri in 2016-2019. The population in this study is the financial statements of Bank Syariah Mandiri from the start operating in 1999 until 2019. The sample in this study is the financial statements of Bank Syariah Mandiri in 2016-2019.

This study uses two variables, namely the volume of financing mudharabah as independent variables and profit-sharing as a dependent variable. Data collection techniques used are document studies. The document under analysis is the financial statements of syari'ah bank. Sources of data collected and used are secondary data sources. The data collected in this research is monthly financial report data of mudharabah financing and profit-sharing of Bank Syariah Mandiri in 2016-2019.

The instrument of data collection in this research is by way of browsing. Browsing is an information search activity through a web browser site. The information sought is the balance sheet and income statement of the monthly publication of Bank Syariah Mandiri in 2016-2019 from www.syariahmandiri.co.id web. Data analysis is an activity to process research data to obtain a conclusion. To simplify the data analysis, researchers use the program IBM SPSS version 23. The data analysis in this study are as follows:

\section{Descriptive Statistics}

Descriptive statistics are used to describe or analyze a statistical research result but not to make broader inferences (Sugiyono, 2013: 21). In this research will be described data from each variable that has been processed so that can be seen the lowest value (minimum), the highest value (maximum), mean (mean) and standard deviation (std. Deviation).

\section{Normality Test}

Normality test aims to see whether the data variable is normally distributed or not. In the use of parametric statistics, work with the assumption that data of each research variable is to be analyzed to form a normal distribution (Sugiyono, 2013: 75). Normality test in this study using Kolmogorov Smirnov test with $5 \%$ significant test.

\section{Simple Correlation Test}

A simple correlation technique is an analysis technique that states the nature of the direction and magnitude of the relationship between two variables. A simple correlation is a number expressing the nature of the movement and strength of the associative ratio between two variables, the correlation coefficient indicating whether a variable has a robust associative ratio with another variable or not (Yuwono, 2005: 78). The magnitude of the relationship is said to be stronger if the two variables change more and more together. The correlation test used is Pearson or Product Moment correlation test. Product Moment correlation test is a statistical test to find the relationship and prove the hypothesis of two variables relationship when the data of the two variables in the form of interval or ratio, and the data source of two or more 
variables are the same (Sugiyono, 2013: 228). However, if the normality test results show that the variable data is not normally distributed, the Product Moment correlation test cannot be performed. Therefore, to test the correlation using Spearman Rank correlation test, research variables do not have to form a normal distribution in this correlation test data.

\section{Coefficient of Determination $\left(\mathrm{r}^{2}\right)$}

The coefficient of determination is a number that states the percentage of total $\mathrm{Y}$ variation described by total X. According to Sugiyono (2013: 231), "This coefficient is called the determinant coefficient because the variance that occurs in the dependent variable can be explained by the variance occurring in the independent variable." The coefficient of determination in this study is used to determine the percentage of variance that occurs in the share of financing can be explained through the variance that occurs in the volume of mudharabah financing.

\section{Results and Discussion}

The object of this research is Bank Syariah Mandiri (BSM) for the period 20162019, because syariah bank, established in 1999, is the largest syariah bank with the asset in Indonesia. Based on the monthly financial report of Bank Syariah Mandiri's balance sheet per December 2019, Bank Syariah Mandiri assets reached Rp $78,831,722,000,000.00$. The total assets of syari'ah commercial banks in Indonesia as of December 2019 based on syari'ah banking statistics is Rp 254,184,000,000,000.00. It means that Bank Syariah Mandiri has $1 / 3$ assets from total assets of sharia commercial banks in Indonesia. Descriptive statistics are statistics that serve to describe or provide an overview of the object under study through sample data or population as is. The following are descriptive statistics of mudharabah financing volume at Bank Syariah Mandiri in 2016-2019, which is seen from the minimum, maximum, average, and standard deviation values: The descriptive statistics of mudharabah volume data volume of Bank Syariah Mandiri from January 2016 to December 2019 reached the lowest (minimum) in April 2019 of 2,732,081, and the highest achievement in June 2016 was 4,669,017. As for the average value (mean) of 3.669.920.98 and standard deviation (Std deviation) of 605,882,010.

Based on table 1.3 descriptive statistics of data for the results of financing at Bank Syariah Mandiri from January 2016 to December 2019, the lowest reach (minimum) in December 2018 amounted to 53,842. It is due to the macroeconomic conditions Indonesia is less conducive to the business so that the condition financial decline and the highest achievement (maximum) in September 2019 amounted to 149,088. As for the mean (mean) of 106,371.18 and the standard deviation of 14,249.926.

Normality test in this study using Kolmogorov Smirnov test with $5 \%$ significant test. The provisions in the Smirnov Kolmogorov test are significant if $\alpha>0,05$, then the data is normally distributed. However, if significant $\alpha<0.05$, the data distribution is not normal. The results of Kolmogorov Smirnov normality test are 0,014. It means sig. $0.014<0.05$, then the data is not normally distributed. In addition, Shapiro Wilk normality test obtained sig. $0.002<0.05$, this indicates the data is not normally distributed. 


\section{Simple Correlation Test}

Simple correlation analysis is an analysis of the relationship and relationship direction between two variables. Direction relationship is expressed in the form of positive or negative relationship, while for the magnitude of the relationship expressed by the correlation coefficient. After conducting the Kolmogrov Smirnov normality test it was found that the distributed research data was abnormal, so it could not use Pearson or Product Moment correlation test as parametric statistic. To know the correlation of mudharabah financing volume with profit sharing in Bank Syariah Mandiri in 20162019 using Spearman Rank correlation test as nonparametric statistic. In the Spearman Rank correlation test is not required normal distributed data.

The results of Spearman Rank correlation test using SPSS version 23 for the correlation of mudharabah financing volume with profit-sharing in Bank Syariah Mandiri in 2016-2019: The volume of financing mudharabah with profit sharing on Bank Syariah Mandiri in 2016-2019 is equal to -0.259 with a significance level of 0.046 at $5 \%$ confidence level. This means that the volume of mudharabah financing with profit sharing in Bank Syariah Mandiri in 2016-2019 has a weak correlation with a negative direction. Correlations that have a negative direction mean that variables change in opposite direction.

To test the research hypothesis can be done by comparing Spearman Rank correlation coefficient calculated with correlation coefficient Spearman Rank table with a significant level of $5 \%$. If the coefficient of correlation $>$ table coefficient correlation, Ho is rejected. If the correlation coefficient calculates $<$ the correlation coefficient of the table, then Ho is accepted. The correlation coefficient Spearman Rank count is 0,259, while for Spearman Rank correlation coefficient table with significant level $5 \%$ and amount of data 60 obtained 0,255. The result is 0.259> 0.255, Spearman Rank correlation coefficient calculates $>$ Spearman Rank correlation coefficient table, then Ha is accepted which means there is a negative relationship between mudharabah financing volume with profit-sharing in Bank Syariah Mandiri in 2016-2019.

\section{Coefficient of Determination $\left(\mathrm{r}^{2}\right)$}

Based on the calculation of Spearman Rank correlation obtained coefficient of mudharabah financing volume with the share of financing at Bank Syariah Mandiri in 2016-2019 amounted to -0.259 or $-25.9 \%$. So that r2 is obtained equal to 0,067 or $6,7 \%$. This means that the variance that occurs in the financing variable of $6.7 \%$ can be explained by the variance that occurs in the variable of mudharabah financing volume, or the amount of mudharabah financing volume determines the profit sharing $6.7 \%$, and $93.3 \%$ by other variables. The conclusion is that the financing share of Bank Syariah Mandiri in 2016-2019 of 6.7\% is determined by a large amount of mudharabah financing in Bank Syariah Mandiri in 2016-2019, while other factors determine 93.3\%.

The result of the research for the description of data is to see the average value of both the volume of mudharabah financing and the share of financing at Bank Syariah Mandiri in 2016-2019 experienced the movement of increase decrease. But for mudharabah financing volume more decreased in every month. The result of Spearman Rank correlation coefficient correlation between mudharabah financing volume with the financing share at Bank Syariah Mandiri in 2016-2019 is equal to - 
0.259 with significance level of 0.046 at $5 \%$ confidence level. This means that the volume of mudharabah financing with profit sharing in Bank Syariah Mandiri in 20162019 has a weak correlation with a negative direction. Correlations that have a negative direction mean that variables change in opposite direction. It means that if the volume of mudharabah financing increases, the share of financing decreases, and if the volume of mudharabah financing decreases the share of financing increases in Bank Syariah Mandiri in 2016-2019.

Based on the calculation of SPSS version 23 obtained Spearman Rank correlation coefficient of calculation is 0.259, while for correlation coefficient Spearman Rank table with a significant level of $5 \%$ and the amount of data 60 obtained 0.255 . The result is 0.259> 0.255, Spearman Rank correlation coefficient calculate greater than Spearman Rank correlation coefficient table. $\mathrm{H}_{1}$ is accepted which means there is a negative relationship between the volume of financing mudharabah with profit sharing in Bank Syariah Mandiri in 2016-2019. As for Ho that states there is no negative relationship between the volume of financing mudharabah with the share of financing at Bank Syariah Mandiri in 2016-2019 was rejected. Also obtained $\alpha=0.046$. The significance value is $0.046<0.05$, then $\mathrm{H}_{1}$ is accepted and Ho is rejected, which means there is a significant negative correlation between the volume of mudharabah financing with the financing share at Bank Syariah Mandiri in 2016-2019 with a correlation coefficient of 0.259 which is included in the weak category with negative direction.

Negative relationship due to the volume of musyarakah financing being higher than the volume of mudharabah financing. The share of musyarakah financing was higher than the profit sharing of mudharabah. It makes the share of musharaka financing contribute substantially to Bank Syariah Mandiri's financing portfolio in 2016-2019. With the decreasing volume of mudharabah financing, the share of mudharabah financing declines, but the overall financing share increases due to the large contribution of the musharaka financing proceeds. Thus, although the volume of mudharabah financing decreases, profit sharing proceeds increase. It makes a negative relationship between the volume of mudharabah financing with the share of Bank Syariah Mandiri financing in 2016-2019.

\section{Conclusion}

The result of research data descriptions by looking at the average value of mudharabah financing volume and profit-sharing in Bank Syariah Mandiri in 20162019 experienced movement of increase and decrease. 2. Spearman Rank correlation results between the volume of mudharabah financing with profit-sharing in Bank Syariah Mandiri in 2016-2019 is equal to -0.259 with a significance level of 0.046 at the level of $5 \%$ confidence. It means that the volume of mudharabah financing with profitsharing in Bank Syariah Mandiri in 2016-2019 has a weak relationship with a negative direction. 


\section{REFERENCES}

Antonio, Muhammad Shafi'i. (1999). Sharia bank is a general introduction. Jakarta: Tazkia Institute.

FORDEBI \& ADESy. (2019). Shariah Accounting: A series of Islamic business and economic concepts and applications. Jakarta: Rajawali Pers.

Giannini, Nur Gilang. (2013). Factors affecting mudharabah financing in sharia commercial banks in Indonesia. Accounting Analysis Journal, 2 (1), 97-103.

Janwari, Yadi. (2019). Jurisprudence of sharia financial institutions. Bandung: Teens Rosdakarya.

Karim, Adiwarman. (2003). Islamic Bank: fiqh and financial analysis. Jakarta: IIIT Indonesia.

Cashmere. (2018). Banks and other financial institutions. Jakarta: Rajawali Pers.

Muhammad. (2002). Sharia bank management. Yogyakarta: UPP AMP YKPN.

---------- (2005). Shariah bank financing management. Yogyakarta: UPP AMP YKPN.

Rafiq, Ahmad. (2004). Contextual fiqih from normative to social meaning. Yogyakarta: Student Literature.

Sugiyono. (2013). Statistics for research. Bandung: Alfabeta.

Susyanti, Jeni. (2011). Management of sharia financial institutions. Malang: Four Two.

Yunus, Mahmud. (1973). Arabic dictionary - Indonesia. Jakarta: Organizational Foundation and Translator of the Qur'an.

Yuwono, Prapto. (2005). Introduction to econometrics. Yogyakarta: ANDI 